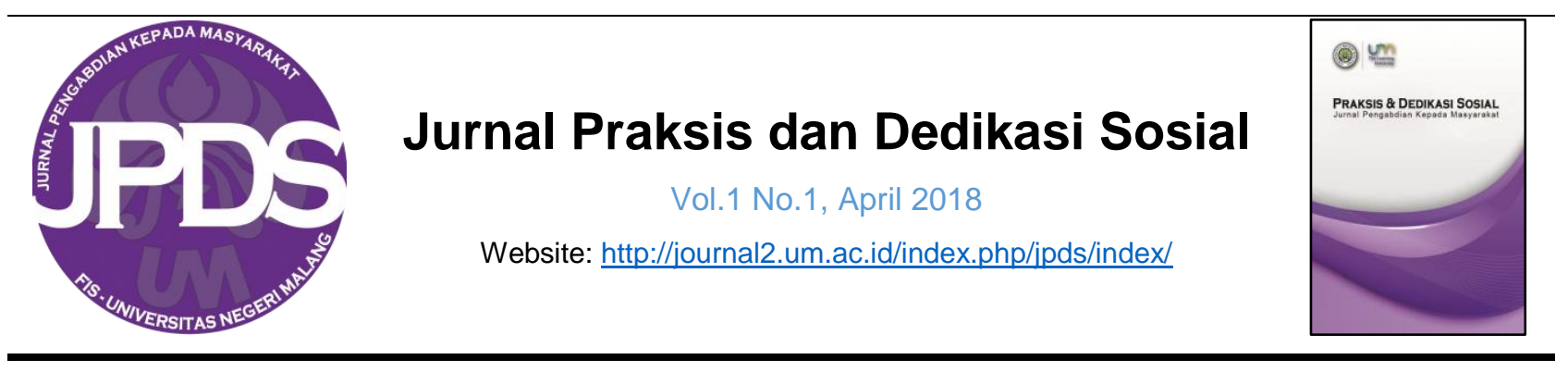

\title{
SOSIALISASI 3-ENDS PADA ANAK DAN REMAJA SEBAGAI UPAYA PEMENUHAN HAK ANAK DI KECAMATAN PESANGGARAN, KABUPATEN BANYUWANGI
}

\author{
Anggaunitakiranantika ${ }^{1}$, Rina Natalia ${ }^{2}$, Mei Rita Kumala ${ }^{3}$ \\ 1,2,3 Jurusan Sosiologi, Fakultas Ilmu Sosial, Universitas Negeri Malang. \\ Diterima 20 Maret 2018, dipublikasikan 30 April 2018.
}

\begin{abstract}
Abstrak
Perkembangan anak sangat dipengaruhi oleh pola asuh yang diberikan orangtua. Pola asuh yang diterapkan oleh setiap keluarga sangat bervariasi. Karakter anak akan ditentukan oleh lingkungan melalui pengalaman yang dibentuk dalam dunia sosialnya, sebagaimana diatur dalam UU no 23 Tahun 2002 tentang Perlindungan anak dan Kebijakan 3-Ends pada 3 isu nasional yang memfokuskan penghapusan kekerasan, Traffiking, dan Rentan Ekonomi yang. Melalui fokus proiritas ini diharapkan semua kekuatan elemen, pemerhati persoalan ini bersinergi untuk mewujudkan dalam masyarakat. Sehubungan dengan itu, perlulah sekali diadakan sosialisasi 3 Ends di kalangan anak dan remaja dalam masyarakat untuk bisa memaksimalkan hak anak dan partisipasi anak dalam pembangunan yang berkelanjutan. Kegiatan ini dilakukan di Kecamatan Pesanggaran, Kabupaten Banyuwangi. Kegiatan dilakukan dengan Action Research menggunakan Focus Group Discussion kepada anak-anak, remaja dan pendamping yang hadir. Kegiatan ini merupakan pengetahuan baru bagi masyarakat sebagai upaya pemenuhan hak anak yang masih belum dipenuhi secara maksimal. Kegiatan ini diharapkan dapat dilakukan secara terjadwal untuk dapat menanggulangi masalah kekerasan dan human trafficking yang semakin rentan terjadi pada anak dan remaja di Kabupaten Banyuwangi.
\end{abstract}

\section{Kata Kunci}

3-Ends, Anak, Remaja, Hak Anak, Kabupaten Banyuwangi

(C) 2018 Penulis

\section{PENDAHULUAN}

Anak merupakan anugerah Tuhan yang diciptakan dengan segala kesempurnaan, sehingga kita sebagai manusia harus menjaga, melindungi dan mengasuh dengan sebaik-baiknya. Perlu dipahami dan diketahui pula bahwa dalam pemenuhan aspek sosial masyarakat yang berkembang, pentingnya peran anak di tengah kehidupan masyarakat dan pengakuan terhadap hak-hak anak seperti disebutkan dalam Penjelasan Umum

\footnotetext{
${ }^{1}$ Surel korespondensi: anggaunita.fis@um.ac.id
}

Undang-Undang Nomor 23 Tahun 2002 tentang Perlindungan Anak sebagai berikut:

"Anak adalah amanah sekaligus karunia Tuhan Yang Maha Esa, yang senantiasa harus kita jaga karena di dalam dirinya melekat harkat, martabat dan hak-hak sebagai manusia yang harus dijunjung tinggi. Hak asasi anak merupakan bagian dari hak asasi manusia yang termuat dalam UndangUndang Dasar 1945 dan Konvensi Perserikatan Bangsa-Bangsa tentang Hak-Hak Anak."

Perhatian yang utama akan peranan anak dalam masyarakat saat ini, perlu dipandang melalui hak partisipasi anak dalam memenuhi 
Sosialisasi 3-Ends Pada Anak dan Remaja Sebagai Upaya Pemenuhan Hak Anak...

kebutuhannnya untuk hidup dan berkembang tanpa ada diskriminasi. Kelompok masyarakat yang diidentifikasi sebagai marjinal justru memandang partisipasi dalam kehidupan masyarakat secara terbuka sebagai hal penting dan prioritas. Yang tergolong dalam kelompok ini adalah kaum perempuan, orang miskin, kelompok minoritas, para pengungsi, orang cacat (berkebutuhan khusus) dan anak yang sampai sekarang masih dipandang sebagai kategori lain dari bangsa manusia (Chambers, Robert, 2002: 98).Setiap anak memiliki sejumlah hak asasi yang salah satunya adalah berpartisipasi dalam kehidupan sosial budaya dan politik. Lazimnya, hak partisipasi anak ini diartikan sebagai hak untuk mengeluarkan pendapat dan didengar suaranya.

Hak partisipasi adalah hak anak untuk berpartisipasi dalam kegiatan sosial dan budaya. Anak berhak berhak berkumpul dan berserikat, menerima dan mencari informasi serta berhak didengar pendapatnya. Pendapat anak itu tidak terbatas di dalam rumah tangga, tetapi juga di dalam masyarakat. Tentu saja hak partisipasi ini disesuaikan dengan usia dan tingkat kematangan anak. Hak partisipasi merupakan hak anak yang penting dalam Konvensi Perserikatan Bangsa-Bangsa tentang Hak Anak. Pelaksanaan hak partisipasi ini umumnya masih dikontrol oleh "orang dewasa", seperti orangtua, guru, aparat kampung maupun aparat negara. Para "orang dewasa" seringkali menempatkan anak sebagai penerima pasif, padahal anak harus diberi kesempatan untuk memainkan peran aktif dalam komunitasnya. Partisipasi bukanlah sekadar keterlibatan anak secara simbolis, melainkan bagaimana memadukan kebutuhan dan pandangan spesifik anak-anak ke dalam proses pembuatan keputusan, baik pada tingkat keluarga, komunitas maupun kota bahkan negara. Partisipasi juga diartikan sebagai "mengambil bagian", atau "The taking part in one or more phases of the process" yang diartikan sebagai mengambil bagian dalam suatu tahap atau lebih dari suatu tahap dalam proses. Proses yang dimaksud adalah proses dalam pembangunan masyarakat. (Khairuddin, 1992:56).

Keluarga juga merupakan lembaga yang paling penting dalam pendidikan dan pengembangan anak selain itu sebagian besar waktu anak dihabiskan bersama keluarga. Keluarga mempunyai peran yang sangat besar bagi perkembangan anak baik perilaku maupun keterampilan hidup. Pola pengasuhan anak didalam suatu keluarga yang ideal apabila dilakukan oleh kedua orang tuanya. Ayah dan ibu bekerja sama saling bahu-membahu untuk memberikan asuhan dan pendidikan kepada anaknya. Mereka menyaksikan dan memantau perkembangan anak-anaknya secara optimal. Namun kenyataannya kondisi ideal tersebut tidak selamanya dapat dipertahankan atau diwujudkan antar satu sama lain. Karena hal ini terkait dengan kebutuhan keluarga yang sifatnya berbeda-beda. Perkembangan anak sangat dipengaruhi oleh pola asuh yang 
Anggaunitakiranantika dkk.

diberikan orangtua. Pola asuh yang diterapkan oleh setiap keluarga berbedabeda, disebabkan berbagai faktor. Faktorfaktor tersebut diantaranya adanya kebutuhan ekonomi yang tinggi dan terus meningkat serta perekonomian keluarga yang kurang memadai, sehingga mengakibatkan salah satu anggota keluarga harus mencari tambahan penghasilan untuk memenuhi kebutuhan hidup agar lebih baik dari sebelumnya.

Melihat kompleksitas persoalan ini dan arus agenda Pembangunan Berkelanjutan(SDGs), pemerintah melalui Kementerian Pemberdayaan Perempuan memberikan prioritas pada 3 isu nasional yaitu penghapusan dalam 3 hal yaitu kekerasan, Traffiking, dan Rentan Ekonomi yang dikenal dengan 3-Ends. Melalui fokus proiritas ini diharapkan semua kekuatan elemen, pemerhati persoalan ini bersinergi untuk mewujudkan dalam masyarakat. Sehubungan dengan itu, perlulah sekali diadakan sosialisasi 3 Ends di kalangan anak dan remaja dalam masyarakat untuk bisa memaksimalkan hak anak dan partisipasi anak dalam pembangunan yang berkelanjutan. Prinsip Pembangunan Berkelanjutan menekankan 3 hal secara komprehensif yaitu aspek ekonomi, sosial, dan lingkngan yang dituangkan kedalam agenda prioritas Perempuan, gender, dan anak, serta kelompok termarginalkan menjadi bagian integral dari program ini.

Oleh karenanya adanya sosialisasi 3 Ends melalui kegiatan pengabdian ini dilakukan guna memberi perhatian dan mengintegrasikan sustainable development goals dalam dalam 3-ends. Agenda Pembangunan Berkelanjutan bersifat komprehensif dan terintegrasi, mensyaratkan keterlibatan aktif semua sektor dengan perspektif yang multidisiplin dan interdisiplin, dengan butir-butir yang saling terkait satu sama lain. Dengan bekal ini, diharapkan pada masa mendatang, masyarakat akan tubuh dan berkembang menjadi masyarakat yang matang dalam karakter dan berdaya saing unggul sehingga mampu mempertahankan peradaban manusia yang berkualitas, terutama pada anak-anak dan remaja sebagai generasi penerus bangsa.

Berdasarkan latar belakang di atas peneliti melihat urgensi permasalahan untuk melakukan Sosialisasi 3-ends bagi anak sebagai strategi penguatan dan pemantapan bagi tercapainya hak anak dalam masyarakat dalam upaya meningkatkan kualitas generasi bangsa menuju masyarakat being atau masyarakat yang memiliki peradaban mulia. Kegiatan ini dilakukan di Kabupaten Banyuwangi, mengingat jumlah anak dan remaja yang terafiliasi dalam Forum Anak Desa sangat heterogen usianya.

\section{METODE}

Pelatihan ini secara mendasar menggunakan pendekatan action research yang mengutamakan proses interaktif antara fasilitator dalam kegiatan sosialisasi dan peserta multi dimensi. Pendekatannya cenderung nominalis, anti-positivis dan idiografis. Kenyataan sosial, seperti halnya makna yang dimiliki oleh seseorang dalam fenomena sosial yang dilakukan secara 
Sosialisasi 3-Ends Pada Anak dan Remaja Sebagai Upaya Pemenuhan Hak Anak...

sengaja muncul karena dibentuk oleh kesadaran dan tindakan seseorang. Karenanya mereka berusaha menyelami jauh ke dalam kesadaran dan subyektivitas pribadi manusia untuk menemukan pengertian apa yang terjadi dalam fenomena sosial.

Kegiatan Sosialisasi ini dilakukan dengan peserta seluruh anggota komunitas anak buruh migran Kabupaten Banyuwangi, anggota Forum Anak Desa, Kader PKK dan perwakilan dari keluarga muda di Kabupaten Banyuwangi. Berdasarkan data ketenagakerjaan yang didaparkan dari BNP2TKI Propinsi Jawa Timur menunjukkan bahwa di tahun 2016 Kabupaten Banyuwangi masuk dalam peringkat 4 dengan jumlah 366, namun pada data tahun 2017 Kabupaten banyuwangi naik peringkat menjadi peringkat 2 sebagai Kabupaten pengirim buruh migran terbesar di Propinsi Jawa Timur. Berdasarkan data yang didapatkan dari Disnakertrans Kabupaten Banyuwangi, Kantong buruh migran yang tersebar di wilayah Kabupaten Banyuwangi berada pada Kecamatan Pesanggaran, sehingga kegiatan ini dilaksanakan di Kecamatan Pesanggaran pada tanggal 19-20 Juni 2017.

- 1. Memahami konsep 3-ends

- 2. Memahami konsep pemenuhan hak anak

-1. Memetakan pengetahuan akan 3-ends

- 2. Menentukan prioritas hak anak

- Praktek menerapkan 3-ends untuk pemenuhan hak anak

Gambar 1. Tiga fase Pelatihan dalam sosialisasi 3-ends.
Fasilitator pelatihan adalah tim pelaksana pengabdian bersama Organisasi Buruh Migran, yaitu Stars Migrant. Ada tiga fase pelatihan dalam mekanisme pelaksanaan kegiatan dalam melakukan Sosialisasi 3-ends pada anak dan remaja sebagai upaya pemenuhan hak anak di Kabupaten Banyuwangi, seperti pada gambar 1 .

\section{HASIL DAN PEMBAHASAN}

Sosialisasi 3 Ends adalah keseluruhan yang dapat orangtua lakukan, hal-hal baik yang besar maupun yang kecil, hari demi hari, yang dapat menciptakan keseimbangan lebih sehat dalam rumah tangga dan hubungan dengan anak-anak. Tindakan orangtua harus menekankan pentingnya perasaan dan membantu orangtua dan anak-anak mengatasi serangkaian emosi dengan pengendalian diri. Kehilangan pengendalian diri dapat berarti bahwa mereka (anak-anak) akan kehilangan uang saku, kehilangan kesempatan mengikuti kegiatan mentoring atau ekstrakurikuler, kehilangan peluang kerja atau bahkan mereka harus ditempatkan di sekolah khusus. Anak-anak membutuhkan keterampilan-keterampilan untuk tumbuh dalam lingkungan positif penuh perhatian dan kaya akan peluang.

Pemenuhan hak anak membantu mewujudkan suatu proses yang berupa pengkombinasian dari pengalaman, kepercayaan dan identifikasi sejak masa kanak-kanak yang pada masa dewasa memberikan perasaan keterkaitan dengan masa lalu maupun arah bagi masa depan. Pembentukan identitas diri sangat bergantung dengan apa yang didapatkan dan dihadapi 
pada masa kanak-kanak seseorang. Kesalahan dalam mendidik anak, orang tua harus selalu berhati-hati menghadapi anak yang masing-masing tak dapat digeneralisasikan tapi secara garis besar orang tua diharapkan waspada terhadap 13 kesalahan dalam mendidik anak yakni: 1) terlalu banyak berkata "jangan"; 2) berkelahi dengan anak; 3) menghina anak; 4) menakutnakuti anak dan mengancap anak; 5) orang tua berbicara terlampau banyak 6) berbicara terlalu keras; 7) mematahkan kemauan anak; 8) mengatakan pada anak bahwa ia jahat; 9) membicarakan karakter anak dihadapan orang banyak; 10) menghukum anak dengan menyuruh ia bekerja; 11) memberi uang anak untuk foya-foya; 13) menuruti semua kemauan anak, dan 13) tidak melatih anak bekerja (Hurlock, 1978: 41).

Perkembangan anak unik karena prosesnya yang bertahap sesuai umurnya. Anak yang sudah di ajarkan berbagai mcam hal akan lebih tahu apa yang harus dikerjakan. Dan anak juga akan mengerti jika diberi sesuatu mereka dapat memilih mana yang baik dan benar. Ini merupakan pendidikan yang baik yang diterapkan orang tua kepada anaknya. Anak berusaha mengerti dan berusaha melakukannya, karena orang tua di anggap sebagai pendidik yang baik. Terkadang dalam mendidik anak tidak semuanya berjalan dengan semestinya. Orang tua harusnya berfikir lebih dari apa yang di inginkan anak. Anak akan senang jika di ajak bermain, berkreasi ataupun belajar tidak dalam suasana sepi karena anak merupakan kepribadian yang ceria. Bahkan jika kita memberikan kebebasan bermain anak akan merasa sangat senang. Hendaknya para orang tua sering-seringlah mengajak bicara dengan anak dan ajukan pertanyaan-pertanyaan sederhana dan yang membuat anak dapat menjawabnya dengan tenang. Si anak akan merasa senang sekali mendapatkan kata-kata baru dan bisa mengucapkannya (Hurlock, 1978: 23).

Berdasarkan wawancara dan kegiatan FGD yang dilakukan di masyarakat menunjukkan bahwa masih banyak orang tua yang belum memiliki pengetahuan yang memadai mengenai pola asuh anak. Masih banyak masyarakat yang mengasuh anak hanya berdasarkan pengetahuan yang ia dapatkan dari masyarakat disekitarnya dan dari orang tuanya atau pola asuh yang dilakukan secara turun temurun. Selain itu pola asuh yang diterapkan oleh orang tua terkadang masih tidak sesuai dengan usia anak. Berlatar belakang kondisi yang demikian, maka subyek sasaran dalam kegiatan ini adalah perwakilan anak-anak yang ditinggal orang tuanya untuk bekerja di luar negeri serta beberapa pendamping yang terdapat di Kecamatan Pesanggaran, Kabupaten Banyuwangi. Dalam kegiatan ini, tidak dibedakan status masyarakat dan pekerjaan masyarakat, agar pemahaman mengenai sosialisasi 3 Ends bagi generasi muda dapat dihadiri semaksimal mungkin oleh anak dan remaja yang ada di Kecamatan Pesanggaran.

Alternatif pemecahan masalah yang dilakukan dalam kegiatan ini adalah dengan menggunakan evaluasi yang dilakukan 
Sosialisasi 3-Ends Pada Anak dan Remaja Sebagai Upaya Pemenuhan Hak Anak...

selama proses berlangsung dan bertumpu pada hasil evaluasi yang didapatkan. Berdasarkan kegiatan pengabdian yang telah dilakukan maka evaluasi proses selama kegiatan berlangsung menggunakan tanyajawab disertai diskusi yang interaktif dengan para peserta. Evaluasi hasil dilakukan dengan memberikan beberapa pertanyaan yang diberikan dalam format pertanyaan tertulis terkait pelaksanaan Sosialisasi 3 Ends untuk pemenuhan Hak anak di Kabupaten Banyuwangi pada peserta yang hadir setelah kegiatan pelatihan sosialisasi dilaksanakan.

Sosialisasi yang disertai dengan adanya tanya jawab merupakan salah satu cara yang paling efektif dalam mengenalkan hal yang dianggap baru kepada komunitas baru untuk dapat diterima lebih baik, baik secara berkelompok ataupun secara individual dalam masyarakat. Memberikan informasi baru yang berguna bagi pengetahuan yang belum pernah didapat dan menanamkan pemahaman positif tentang sosialisasi 3 Ends untuk pemenuhan hak anak yang masih jarang diperkenalkan kepada masyarakat, kemudian diterapkan oleh orang tua yang saling berinteraksi antara satu dengan yang lain di Desa Pesanggaran adalah substansi dari kegiatan ini. Hal ini didasari pada fakta bahwa dalam keseharian para orang tua secara menyeluruh banyak yang masih tidak mengetahui atau paham kegunaan dari pola asuh anak dan pencegahan kekerasan seperti halnya bullying dan trafficking, yang akan meningkatkan kualitas karakter dan berdaya saing unggul sehingga mampu mempertahankan peradaban manusia yang berkualitas.

Selama kegiatan berlangsung, peserta bersemangat mengikuti kegiatan sosialisasi ini dikarenakan adanya kegiatan ini ternyata merupakan pengetahuan dan wawasan baru yang didapatkan oleh peserta yang hadir. Selain itu, adanya materi tentang 3 Ends bagi para ibu-ibu untuk mendidik anak dengan cara yang dikhususkan bagi generasi muda dalam memaksimalkan pemenuhan hak anak kualitas diri dalam masyarakat luas. Adanya pemaparan materi dari tim pengabdian turut menambah lengkap pengetahuan yang didapatkan bagi para ibu-ibu untuk dikembangkan sebagai sebuah sosialisasi dalam pemenuhan hak anak.

Dalam kegiatan diskusi dan tanya jawab para pendamping anak buruh migran terlihat sangat antusias dalam mengikuti pelatihan ini ditambah lagi sebagian besar peserta sosialisasi merupakan anak dan remaja dari komunitas mantan buruh migran di Desa Pesanggaran dan pelatihan ini merupakan hal yang baru dan juga pengetahuan baru yang di dapat anak dan remaja menginggat dengan keadaan saat ini merupakan keadaan yang sangat awam dengan kekerasan dan human trafficking di Kabupaten Banyuwangi.

Pertanyaan yang diajukan oleh peserta tidak hanya diajukan pada saat tanya jawab saja karena waktu yang sangat terbatas, namun setelah selesai kegiatan pelatihan. Pertanyaan yang di utarakan ibu-ibu seputar pola asuh dan pemenuhan hak yang mereka terapkan kepada anak mereka dan juga masalah yang dialami anak para peserta 
pelatihan di lingkungan sekolah, keluarga maupun di lingkungan masyarakat. Menariknya, ada peserta pelatihan yang sampai meneteskan air mata saat menyampaikan pertanyaan tentang anaknya yang sangat legowo dalam menyikapi sesuatu hal, ada juga yang menceritakan bahwa anak mereka di bully entah karena suatu hal sampai meninggalkan bekas luka di sekolah tempat anak peserta pelatihan bersekolah.

Seperti contohnya bullying, tidak hanya di kota besar namun faktanya kini bullying sudah terjadi di desa. Dengan pengetahuan orangtua yang sangat terbatas tentang bullying, banyak dari orangtua yang tidak tau bahwa anak mereka telah menjadi korban bullying dan orangtua tidak tau bagaimana cara untuk untuk mengatasi maslah bullying. Dengan tanya jawab dengan pemateri, maka dijelaskan tentang bullying itu yang seperti apa, bagaimana cara menanggulanginya, dan bagaimana sikap orangtua jika anaknya menjadi korban bullying. Dengan diberikan contoh yang merupakan dari pengalaman pemateri sendiri, peserta menjadi mudah memahami tentang bullying dan cara mengatasinya.

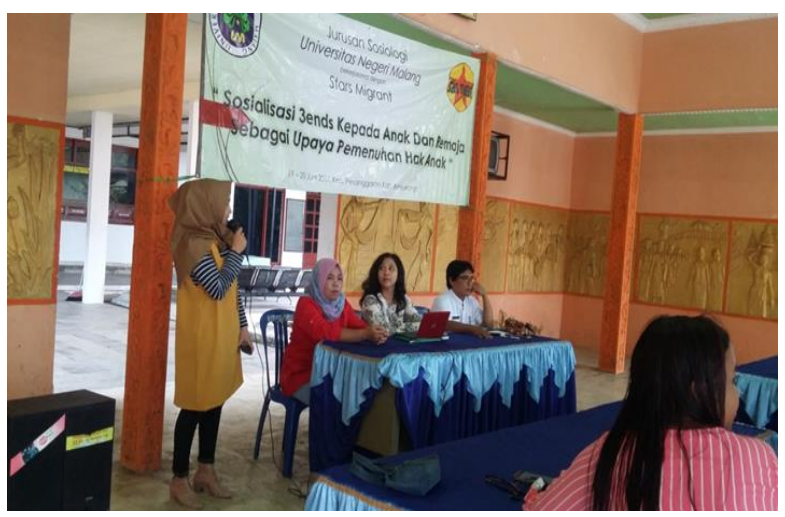

Gambar 2. Pendamping anak mengikuti sesi tanya jawab pada kegiatan Sosialisasi 3-Ends (Sumber: Dokumentasi penulis diambil pada 19 Juni 2017 pukul 13.20 WIB)
Selain masalah bullying, di Desa Pesanggaran juga ditemukan tentang permasalahan gaya hidup anak. Hal ini berdasarkan pertanyaan dari ibu yang bercerita tentang anak remajanya yang tidak patuh dengan orangtua. Usia remaja memang usia labil seorang anak yang dimana anak masih terus berubah. Dilingkungan desa dan rumahnya sebagian besar anak yang berada di usia smp dan sma telah memiliki sepeda motor yang bagus-bagus. Hal ini dipengaruhi oleh banyak dari orangtua yang memilih untuk bekerja di luar negeri sebagi tenaga kerja wanita atau tenaga kerja Indonesia yang kemudian menuruti permintaan anak dengan mudah.

Banyak peserta yang bertanya kepada pemateri secara personal tentang masalah yang dihadapinya, ada juga yang bertanya tentang apakah pola asuh yang telah ia berlakukan selama ini sudah benar atau belum. Dari banyaknya pertanyaan yang diajukan menunjukkan bahwa peserta sangat antusias dalam kegiatan pelatihan dan memiliki keinginan untuk menambah pengetahuan baru yang selama ini mereka tidak ketahui. Adanya hadiah atau doorprizes

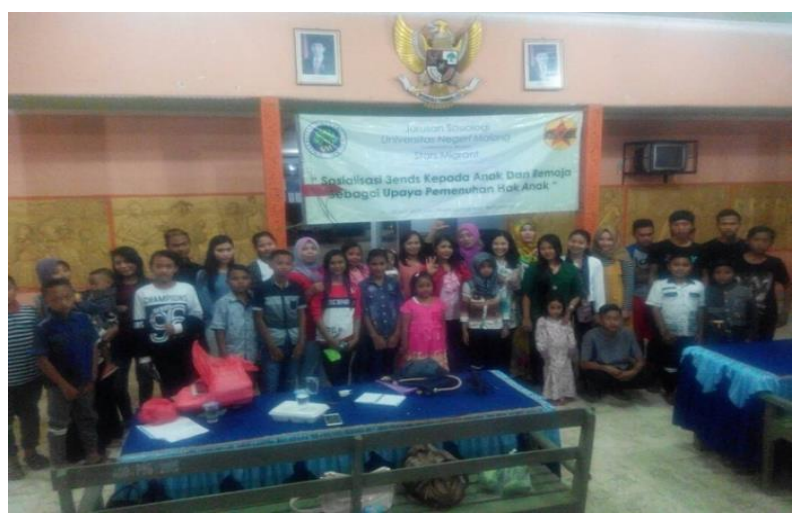

Gambar 3. Seluruh Peserta Sosialisasi 3-Ends (Sumber: Dokumentasi Penulis, diambil pada 20 Juni 2017 pada 11.17 WIB). 
Sosialisasi 3-Ends Pada Anak dan Remaja Sebagai Upaya Pemenuhan Hak Anak...

semakin menambah antusiasme peserta pelatihan ini untuk melakukan disukusi tanyajawab dan sharing karena para peserta ini adalah ibu-ibu jadi mereka melakukan diskusi dengan nyaman dan tanpa ada rasa canggung. Para peserta pelatihan juga saling bertukar pikiran dan juga pengalaman dalam mengasuh buah hati mereka. Ada beberapa ibu-ibu yang mengikuti pelatihan ini dengan membawa anak mereka yang masih balita menambah suasana semakin semarak dan juga menambah bahan diskusi dalam sosialisasi.

Ada berbagai faktor pendukung dan penghambat yang dapat diidentifikasi dari pelaksanaan kegiatan pengabdian ini. Berbagai faktor pendukung diantaranya adalah: 1) adanya kerjasama yang baik antara tim pengabdian kepada masyarakat dengan pihak dari Desa Pesanggaran dan Migrant Care Banyuwangi dalam mengurus kegiatan sampai terlaksananya hingga selesai kegiatan pelatihan; 2) adanya kerjasama yang baik antara tim pengabdian kepada masyarakat dengan para ibu-ibu dan anak - anak usia SD sampai SMA yang telah berpartisipasi secara aktif dalam pelaksanaan kegiatan dan evaluasi hasil; 3) adanya kerjasama yang baik antara tim pengabdian masyarakat dengan Perangkat Desa Pesanggaran yang juga bersedia menyediakan ruangan dan segala fasilitasnya dalam pelaksanaan kegiatan. Adapun berbagai factor penghambat diantaranya adalah: 1) kegiatan hanya memungkinkan untuk dilaksanakan sekali saja di Desa Pesanggaran sehingga tidak cukup untuk menampung aspirasi dan keinginan dari para peserta pelatihan; 2) kegiatan ini dirasa belum mampu untuk membangun pemahaman para ibu-ibu dan juga anak- anak mantan buruh migran tentang pentingnya menerapkan 3 Ends mengmemenuhi hak anak asuh anak untuk meningkatkan kualitas diri karena peserta yang hadir hanya sebagian kecil dari warga masyarakat.

Hasil evaluasi menunjukkan dari 40 peserta yang sebagian besar perserta terdiri dari stars migrant yang mengisi secara lengkap menyatakan bahwa $85,10 \%$ peserta merasa kegiatan yang dilakukan sangat bermanfaat dan mendapatkan pengetahuan baru dibandingkan sebelum mengikuti sosialisasi 3 End ini. Sebanyak 74,46\% peserta berniat untuk menerapkan pola asuh seperti yang telah di jelaskan pada saat pelatihan.

Dari hasil yang didapatkan dari evaluasi yang telah diisi, menunjukkan bahwa pada kesempatan lain, tim pengabdian perlu untuk mengulangi kegiatan serupa dengan tujuan membangun kesadaran dan memberikan pengetahuan kepada ibu-ibu dan anak - anak, mengenai sosialisai 3 Ends bagi generasi muda dalam memaksimalkan kualtas diri dalam masyarakat dan dengan kegiatan lain yang mampu menambah wawasan dan pengetahuan ibu-ibu dan sosialisasi 3 ensd untuk selalu cermat dan cerdas dalam mengasuh anak dan paham akan pemenuhan hak anak untuk meningkatkan kualitas diri anak dalam masyarakat. 


\section{KESIMPULAN}

Karakter anak akan ditentukan oleh lingkungan melalui pengalaman yang dibentuk dalam dunia sosialnya. Kegiatan sosialisasi 3 Ends sebagai upaya pemenuhan hak anak akan membangun kesadaran dan memberikan pengetahuan baru bagi ibu-ibu dan juga anak-anak yang berada di Desa Pesanggraan. Bentuk kegiatan sosialisasi 3 Ends dirasa sangat tepat sebagai pengetahuan bagi anak dan remaja di Kecamatan Pesanggaran, Kabupaten Banyuwangi yang rentan dengan kekerasan dan trafficking. Forum ini bermanfaat sebagai salah satu upaya pemenuhan hak anak yang tepat bagi anak sehingga menjadikan anak yang matang dalam karakter dan berdaya saing unggul. Sebagian besar pendamping anak dan remaja, seperti Ayah, Paman, Bibi, Nenek dan kakek akan menerapkan pola asuh egaliter seperti yang telah dijelaskan pada saat pelatihan.

Adapun saran dalam kegiatan ini adalah Kegiatan sosialisasi 3 Ends sebagai upaya pemenuhan hak anak perlu dilakukan dan dikembangkan di tempat lain. Selanjutnya, perlu dilakukan pendampingan untuk keberlangsungan 3 Ends secara terstruktur dan berkesinambungan agar pemahaman dan pengetahuan ini mampu untuk dikonstruksikan meluas bagi warga masyarakat Desa Pesangggaran pada khususnya.

\section{DAFTAR RUJUKAN}

Anggaunitakiranantika, dalam

Candraningrum, Dewi (ed) 2015.

Konstruksi Sosial Perempuan Buruh Migran Malang di HongKong: Social

Prestige vs Lilitan Hutang dalam

Kebijakan Pembangunan Gender:

Kepemimpinan, Ekologi, Kesehatan

Reproduksi\& Seksual. Jakarta:

Percetakan Jalasutra.

Chambers. R. 2002. Participatory

Workshops: A Sourcebook of 21 Sets of Ideas and Activities, London \& Sterling VA: Earthscan.

Heyzer. N. \& Vivian. W. 1994 "Domestic

Workers in Transient Overseas

Employment: Who Benefits, Who Profits?"

In the Trade in Domestic Workers:

Causes, Mechanisms and Consequences of International Migration. Edited by N.

Heyzer, G. L. A'Nijeholt and N.

Weerakoon. Kuala Lumpur, Malaysia:

Asian and Pacific Development Centre.

Hurlock. E. 1978. Child Development. The University of Michigan, United States:

McGraw Hill.

Ihromi. T.O. 2000. Sosiologi Keluarga. Jakarta: Rineka Cipta.

Khairuddin. 1992. Pembangunan Masyarakat: Tinjauan Aspek Sosiologi, Ekonomi, dan Perencanaan. Yogyakarta: Liberty.

Levitt. P. 2001. The Transnational Villagers. Berkeley and Los Angeles: University of California Press.

Newman, Lawrence. 2000. Qualitative and Quantitative: a perspective on Social Science Research. London: Routletge.

Nihayah, Ulin. 2015. Mengembangkan Potensi Anak: Antara Mengembangkan Bakat dan Ekploitasi. Jurnal Sawwa Volume 10 No 2 hal 135-150. Semarang: Universitas Negeri Islam walisongo.

Suharto, Edi. 2006. Membangun Masyarakat Memberdayakan Rakyat. Bandung: PT. Refika Aditama 